\title{
Implementasi Metode Enumerasi Implisit Untuk Penyusunan Menu Makanan Berdasarkan Kebutuhan Kalori
}

\author{
Adhie Saputra ${ }^{1}$
}

\author{
Jong Jek Siang ${ }^{2}$ \\ j___siang@yahoo.com
}

\author{
Lucia D Krisnawati ${ }^{3}$ \\ krisna@ukdw.ac.id
}

\begin{abstract}
A simple eating disorder can create variety of disease. In this research, a diet menu created based on the needs of nutrition, using implicit enumeration method. The system will produce minimum price diet menu arrangement 3 times a day for a week, yet still fulfill customer's nutrition need. Implicit Enumeration Method is used to generate the menu with minimum price. More foods used in this calculation, the implicit enumeration utilization become more optimal. For 10 menus were used in the calculation, the node exploration will be $27.3 \%$ of the actual solution, whereas for 15 menus were used, the node exploration will be just $10.9 \%$.
\end{abstract}

Keywords : Enumerasi Implisit, diet, menu makanan

\section{PENDAHULUAN}

Obesitas merupakan salah satu hal yang ditakuti masyarakat pada masa ini, terutama oleh pihak hawa. Ketakutan akan obesitas sering kali membawa pengaruh buruk. Orang yang takut akan obesitas sering kali melakukan diet secara membabi buta. Padahal tubuh mereka tetap memerlukan asupan gizi dan mineral yang lengkap. Karena hal ini, sekarang mulai banyak dikenal program menu sehat. Program ini dimaksudkan untuk membantu pihak yang ingin menaikkan atau menurunkan berat badan namun tetap memenuhi kebutuhan nutrisinya.

Beberapa rumah makan menyediakan menu khusus untuk diet. Salah satunya adalah Kantin Shintya, yang menyediakan menu katering. Salah satu jenis katering yang paling banyak diminati oleh para pelanggan kantin Shintya adalah catering untuk menurunkan atau menaikkan berat badan.

Dalam penelitian ini dibuat sistem yang menghasilkan susunan menu dengan harga seminimal mungkin, tapi dengan memenuhi kendala diet sehat. Nutrisi yang diperhatikan adalah kebutuhan kalori, lemak, protein, dan karbohidrat. Metode yang dipakai untuk membentuk susunan makanan adalah Enumerasi Implisit.

\footnotetext{
${ }^{1}$ Teknik Informatika, Fakultas Teknologi Informasi, Universitas Kristen Duta Wacana, Yogyakarta

${ }^{2}$ Sistem Informasi, Fakultas Teknologi Informasi, Universitas Kristen Duta Wacana, Yogyakarta

${ }^{3}$ Teknik Informatika, Fakultas Teknologi Informasi, Universitas Kristen Duta Wacana, Yogyakarta
} 


\section{DASAR TEORI}

\subsection{Pemodelan Matematika}

Model matematika yang digunakan dalam penelitian ini adalah sebagai berikut:

Minimumkan $\mathrm{z}=c_{1} x_{1}+c_{2} x_{2}+\ldots+c_{\mathrm{n}} x_{\mathrm{n}}$ dengan $c_{\mathrm{j}} \geq 0 \forall \mathrm{j}$

Dengan kendala:

$$
\begin{aligned}
& a_{11} x_{1}+a_{12} x_{2}+\ldots+a_{1 \mathrm{n}} x_{\mathrm{n}} \leq b_{1} \\
& a_{21} x_{1}+a_{22} x_{2}+\ldots+a_{2 \mathrm{n}} x_{\mathrm{n}} \leq b_{2} \\
& \ldots \\
& a_{\mathrm{m} 1} x_{1}+a_{\mathrm{m} 2} x_{2}+\ldots+a_{\mathrm{mn}} x_{\mathrm{n}} \leq b_{\mathrm{n}} \\
& x_{1}, x_{2}, \ldots, x_{\mathrm{n}}=\{0,1\}
\end{aligned}
$$

dengan

$\mathrm{z}=$ harga minimum yang akan dicari

$\mathrm{c}_{\mathrm{i}}=$ harga dari seporsi makanan ke-i $(\mathrm{c}=1,2,3, \ldots, \mathrm{n})$

$\mathrm{x}_{\mathrm{i}}=$ jenis makanan ke-i $(\mathrm{x}=1,2,3, \ldots, \mathrm{n})$

$\mathrm{a}_{\mathrm{ij}}=$ kandungan nutrisi-i dari makanan ke-j $(\mathrm{i}=1,2,3, \ldots, \mathrm{m})$

$$
(j=1,2,3, \ldots, n)
$$

$\mathrm{b}_{\mathrm{j}}=$ batas nutrisi- $\mathrm{j}$ yang dapat ditoleransi $\quad(j=1,2,3, \ldots, n)$

\subsection{Enumerasi implisit}

Dasar dari metode enumerasi implisit adalah melakukan enumerasi sebagian dari kemungkinan penyelesaian. Dengan enumerasi implisit, kemungkinan penyelesaian maksimal yang berjumlah $2^{\mathrm{n}}$ buah dapat berkurang. Dalam enumerasi implisit, penyelesaian yang tidak fisibel atau akan menghasilkan nilai yang kurang optimal dibanding nilai yang telah ada akan diabaikan. ( Siang, 2011).

Metode enumerasi implisit sendiri dapat menyelesaikan masalah pemrograman linear dengan baik bahkan jauh lebih baik dari metode branch and bound (Sabagh, 2008). Penggunaan metode enumerasi implisit akan menghasilkan perhitungan optimal bila menggunakan 10 variabel saja sehingga proses perhitungan dan pengecekan penyelesaian ( Beal, 2011 ). Salah satu penerapan proses enumerasi implisit adalah untuk membangun database mengenai pengenalan pola yang dapat dikenali oleh sistem ( Milikainen, 2008). Proses enumerasi implisit sendiri dijelaskan pada gambar 1.

\subsection{Nutrisi}

Nutrisi adalah zat kimia organik dan anorganik yang diperoleh dari makanan dan minuman dan digunakan tubuh untuk memenuhi kebutuhannya akan zat-zat tertentu 
(Mahan, 2008). Kebutuhan nutrisi untuk diet secara umum dilihat dari pemenuhan kalori. Selain kalori selaku kebutuhan utama, nutrisi lain yang berpengaruh adalah pemenuhan 3 nutrisi utama yaitu, protein, lemak, dan karbohidrat. Dengan terpenuhinya 4 kebutuhan di atas, sebuah proses diet dapat dikatakan wajar. ( Haas, 2006 ). Data nutrisi yang digunakan oleh sistem diambil dari Mahmud, (2009). Data kandungan nutrisi tiap makanan didapat dari ahli gizi Kantin Shintya

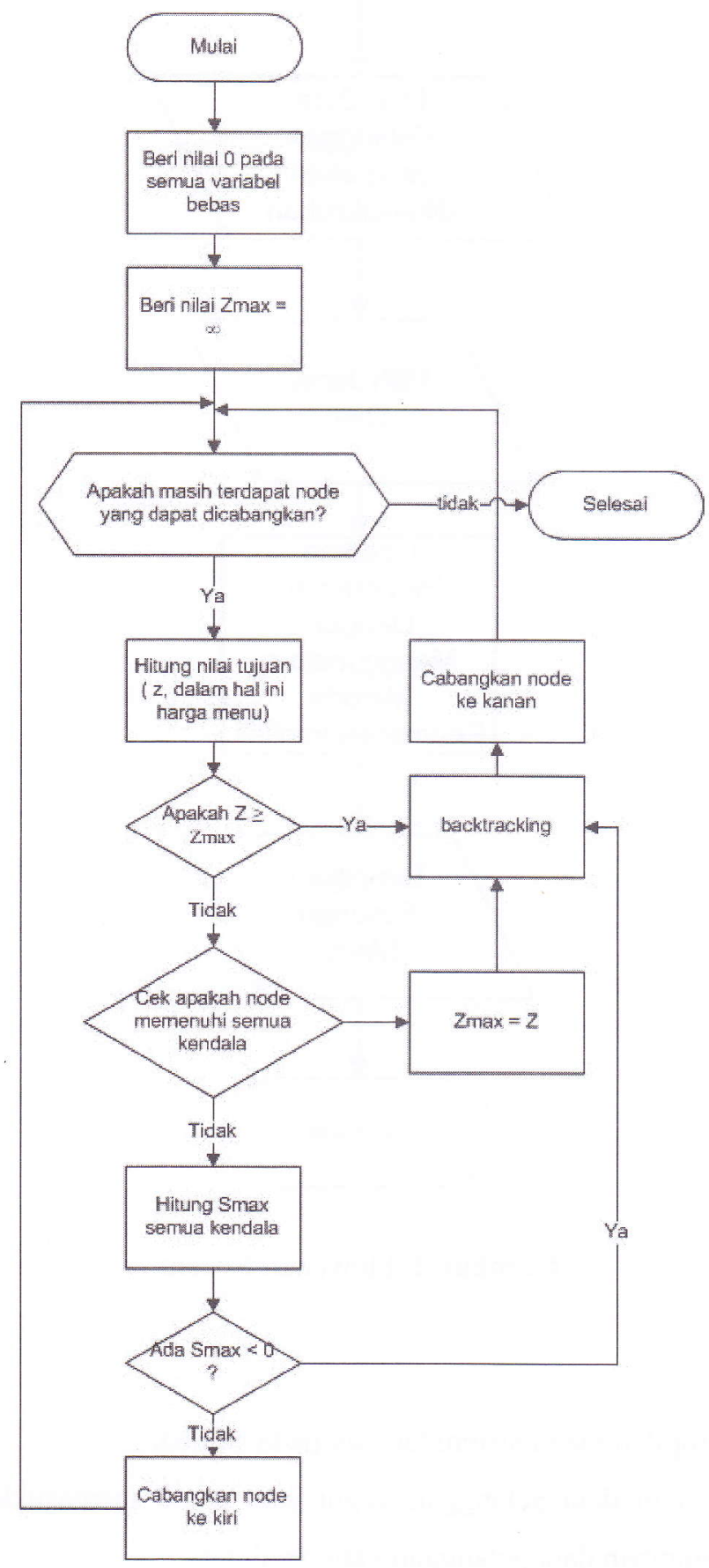

Gambar 1. Proses Enumerasi Implisit 


\section{IMPLEMENTASI SISTEM}

\subsection{Alur Kerja Sistem}

Alur kerja sistem tampak pada gambar 2. Sistem diimplementasikan dengan menggunakan program Visual Studio 2008 dan Oracle 10g Express Edition.

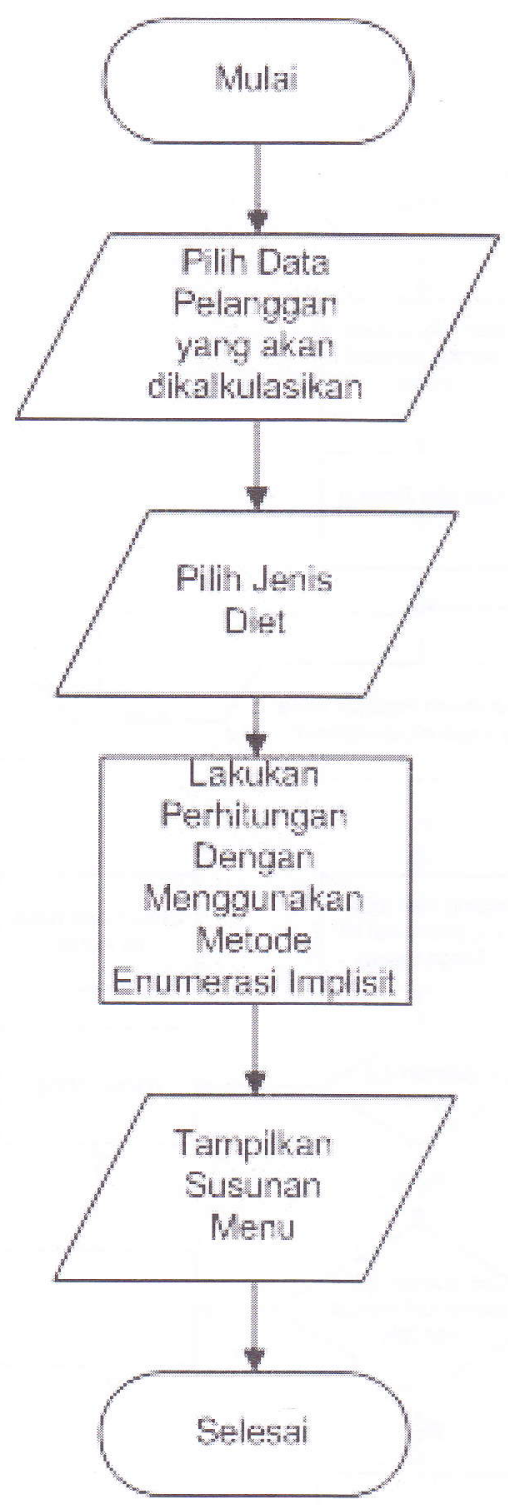

Gambar 2. Flowchart Sistem

\subsection{Menu Sistem}

Ada beberapa tampilan menu sistem tampak pada gambar 3-7

a. Menu input dan edit data pelanggan, digunakan untuk memasukkan data pelanggan baru ataupun mengubah data pelanggan yang telah ada. 


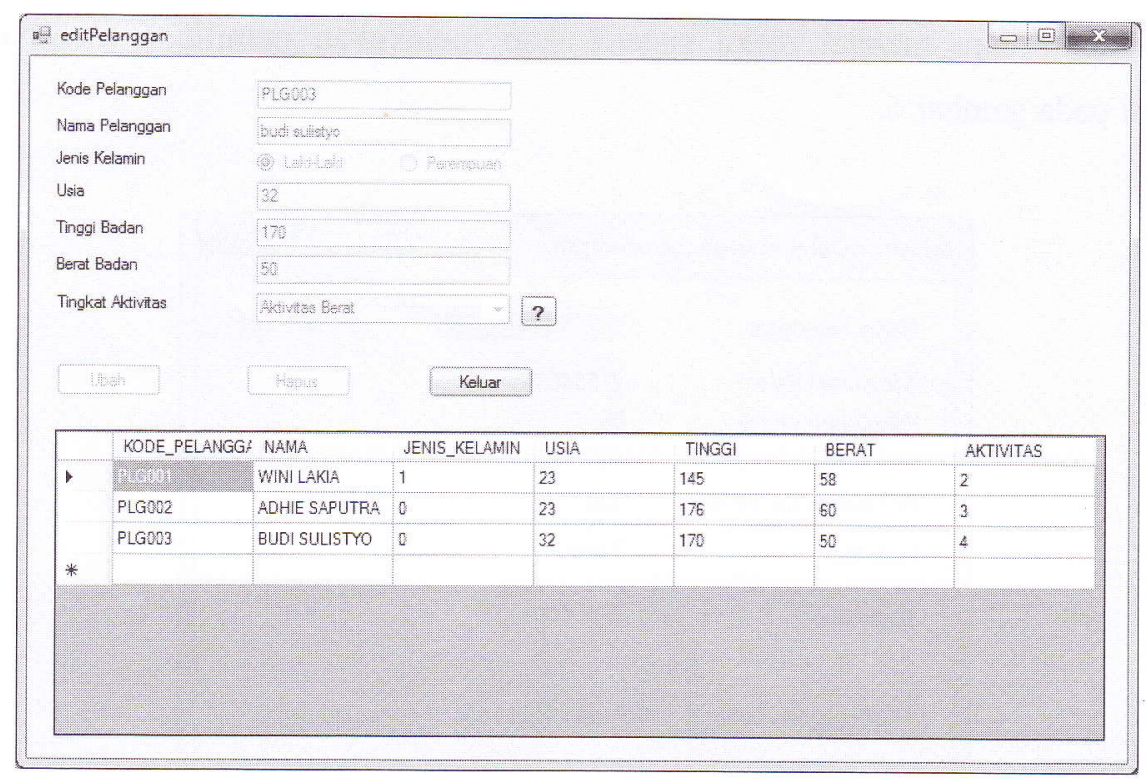

Gambar 3. Menu Input dan Edit Pelanggan

b. Menu input dan edit data menu makanan, digunakan untuk memasukkan data menu makanan baru maupun mengubah data menu makanan yang telah ada.

\begin{tabular}{|c|c|c|c|c|c|c|c|c|}
\hline \multicolumn{7}{|c|}{ a. inputMenu } & \multicolumn{2}{|c|}{ 다. 미 } \\
\hline \multicolumn{2}{|c|}{ Kode Menu } & \multicolumn{3}{|l|}{ dewo: } & & & & \\
\hline \multicolumn{9}{|c|}{ Nama Meru } \\
\hline \multicolumn{9}{|c|}{ Kandungan Kälori } \\
\hline \multicolumn{9}{|c|}{ Kandungan Protein } \\
\hline \multicolumn{9}{|c|}{ Kandungan Lemak } \\
\hline \multicolumn{9}{|c|}{ Kandungan Katohidrat } \\
\hline \multicolumn{9}{|c|}{ Harga } \\
\hline \multicolumn{2}{|c|}{ Simpan } & Reset & \multicolumn{2}{|c|}{ Keluar } & & & & \\
\hline & KODE_MENU & NAFA_MENU & KALORI & PROTEIN & LEMAK & KARBOHIDRAT & HARGA &. \\
\hline \multirow[t]{11}{*}{$\Rightarrow$} & 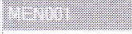 & AYAM LADA HIT... & 666500 & 15 & 5 & 31 & 6000 & E \\
\hline & MENSOZ2 & AYAM ASAM MA & 623677 & 15 & 5 & 40 & 6000 & \\
\hline & MENOCO3 & AYAM SAUS EA... & 622495 & 16 & 5 & 31 & 6000 & \\
\hline & MENOOA & AYAM HAINAM & 620300 & 15 & 4 & 30 & 7000 & \\
\hline & MENOES & AYAM GORENG ... & 598200 & 14 & 5 & 31 & 5500 & \\
\hline & MENMS & SAPILADA HITAM & 895230 & 20 & 9 & 35 & 8000 & \\
\hline & MENWOT & SAPI BUIMBU R... & 917800 & 20 & 9 & 35 & 8000 & \\
\hline & MENGSO & SUP BUNTUT & 729960 & 17 & 7 & 29 & 7000 & \\
\hline & MENGOS & SATE SAPI & 949675 & 20 & 9 & 32 & 8000 & \\
\hline & MENO10 & BISTIK SAPI & 775650 & 19 & 9 & 29 & 7000 & \\
\hline & MENO11 & SAPO TAHU & 498875 & 8 & 3 & 19 & 5000 & \\
\hline+1 & MELin1? & TAUli DAuEn & Emman & in & . & 10 & crens & \\
\hline
\end{tabular}

Gambar 4. Menu Input dan Edit Menu Makanan

c. Menu untuk memilih pelanggan yang akan dilakukan proses penyusunan menu makanan selama seminggu. Terdapat 2 pilihan pemilihan menu yang akan disusun. Bila disusun secara otomatis, sistem akan langsung menuju gambar 7 namun bila pemilihan 
dilakukan secara manual maka sistem akan melakukan pemilihan menu makanan seperti pada gambar 6 .

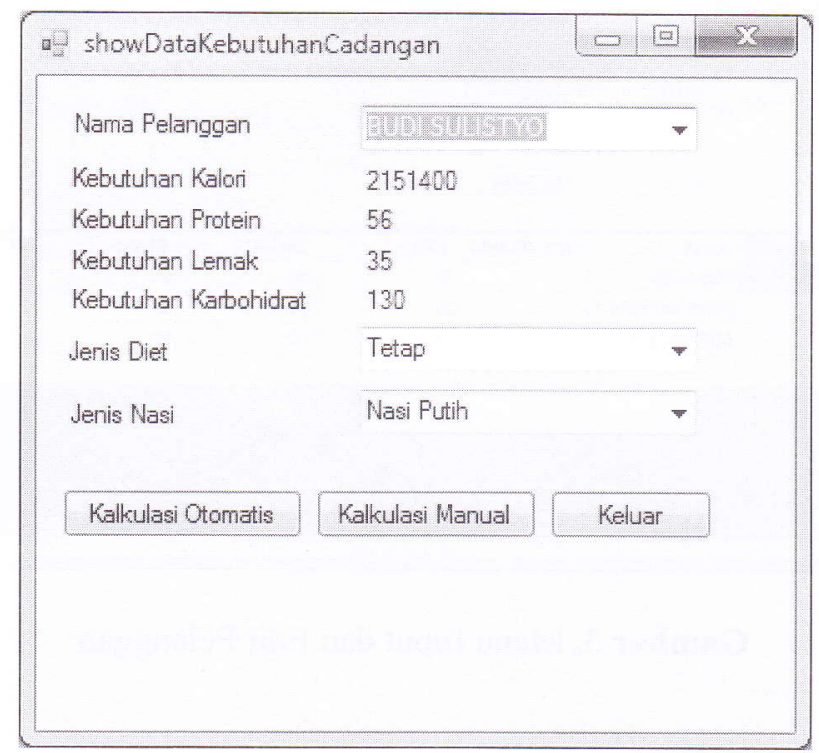

Gambar 5. Menu Pemilihan Pelanggan

d. Menu pilihan menu makanan yang akan disusun.

\begin{tabular}{|c|c|c|c|c|}
\hline \multicolumn{4}{|l|}{ - pilikanMenu } & \multirow{2}{*}{ 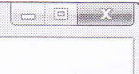 } \\
\hline AYAM LADA HITAM & AYAM_BAKAF & EMPAL_GEPUK & D OSENG TERI & \\
\hline AYAMASASAM MANIS & AYAM_GORENG_MENTEGA & A. SEMUR_SAPI & OSENG BunCIS & \\
\hline AYMM SAUS BAREEQUE & DAYAM_KUKUS & SAPF_GOFENG_CRISPY & Cuncis CA & \\
\hline AYAM HANAAM & 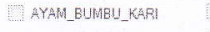 & (1) THU_CA & CIIALANCA & \\
\hline AYMM GORENG TEFUNG & II AYAM_EUMBU_RENDANG & GUN_TAHU & FU FU YUNG HAY & \\
\hline SAPL LADA HITAM & AYMAM_EUPBO_KUNHNG & TAHU_ISI_UDANG & CAPCAY & \\
\hline SAPI BUMBU RENDANG & DAYAH_KECAP & KAKAP GORENG & SAYYUR TERONG & \\
\hline SUP BUNTUT & DI AYAM_MASAK__AEHE & GURAMEH ASAM MANIS & SAYUR BUNCOS & \\
\hline SATE SAFI & DAYAM_TIM & CUDANG MADU & PAKLAYCA & \\
\hline ] BISTKK SAPI & DI AYAA_BUMBBU_ASIN & CUMI MASAK PEDAS & OMELET TELUR & \\
\hline DS SAPO TAHU & DSATE_AYMA & S.AYUR ASEM & & \\
\hline TAHU BAKSO & SISPC_CHCKEN & SAYUR BEANG & & \\
\hline TAHUI MASSAK TAUCO & DICKEN_ROLL & SUP FOLADE & & \\
\hline KAKAP ВAKAF: & CHICKEN_DRUMSTICK. & SUP BAKSO & & \\
\hline 1] KAKAP ASAM MAMIS & WJ FRIED_CHICKEM_MEATEALLL & L. SUP JAGUNG & & \\
\hline DI GURAMEH BUMBU KUNING & G] CHICKEN_KATSU & 1. SUP KRMM AYAM & & \\
\hline TI GURAMEH GORENG & DEISTIK_AYAM & SOTO AYAM & & \\
\hline E. UDANGG GOFENG TEPUNG & II BISTK_AYAM & SAYYR GORI & & \\
\hline CUMIGORENG TEPUMG & EAPI_SAUS_BARREQUE & ESAYUR UPANG & & \\
\hline UDANG BAKAR & S.API_EULAOU_KAFI & OSENG TEMPE & & \\
\hline Hitung & & & Tampi & \\
\hline
\end{tabular}

Gambar 6. Menu Pemilihan Menu Secara Manual

e. Tampilan hasil akhir berupa daftar menu makanan selama 1 minggu, beserta dengan harganya 


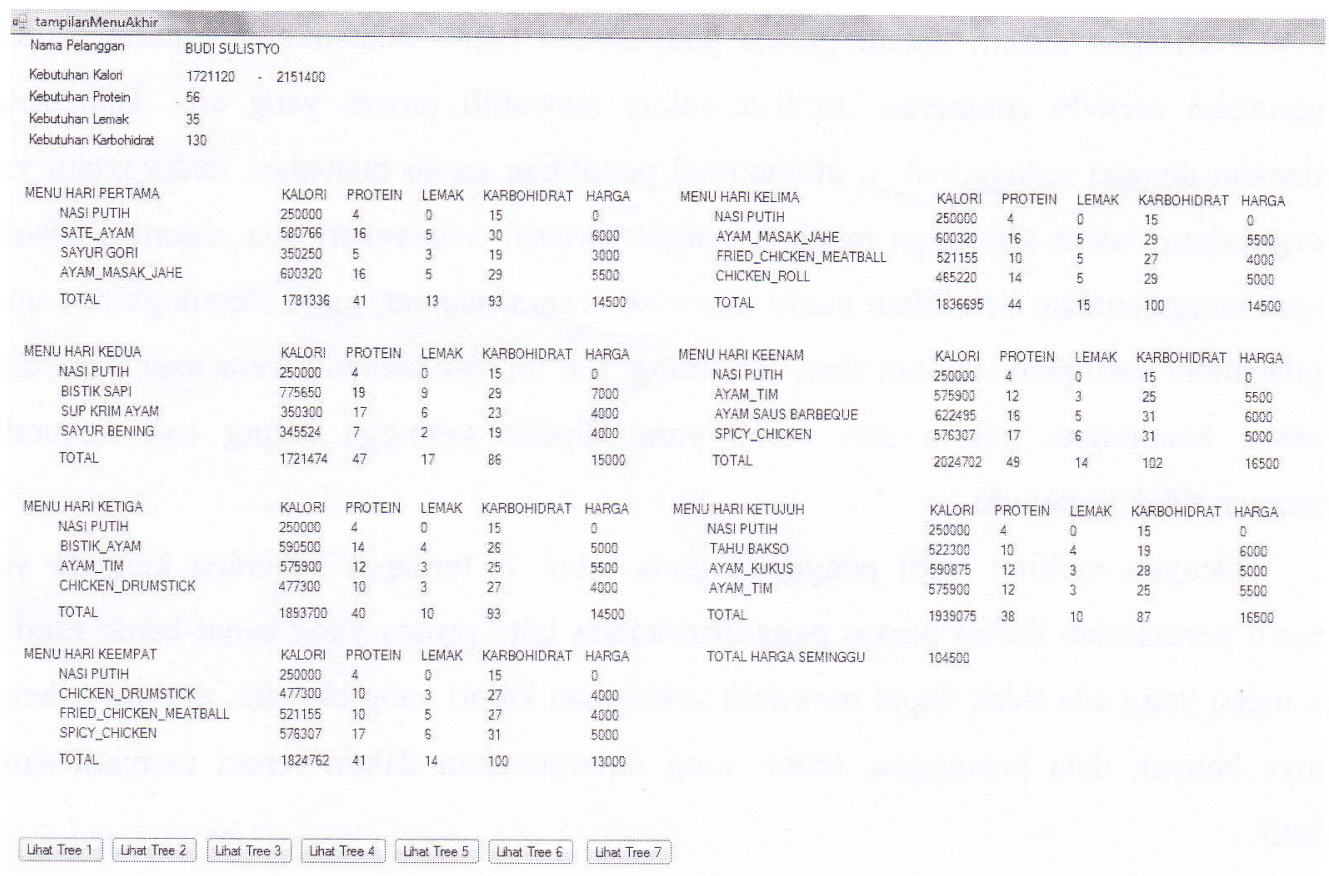

Gambar 7. Tampilan Susunan Menu Makanan

\section{EVALUASI PENERAPAN SISTEM}

\subsection{Penerapan Metode}

Evaluasi dilakukan dengan membandingkan keluaran sistem dengan kondisi riil di Kantin Shintya selama 7 hari untuk 10 orang pelanggan. Melalui proses evaluasi pertama, didapatkan hasil sebagai berikut:

Tabel 1.

Tabel Pengujian Implementasi Metode

\begin{tabular}{|c|c|c|c|c|c|}
\hline Pelanggan & $\begin{array}{c}\text { Kebutuhan nutrisi } \\
\text { terpenuhi? }\end{array}$ & $\begin{array}{c}\text { Munculnya } \\
\text { menu baru }\end{array}$ & Total Harga & $\begin{array}{c}\text { Harga } \\
\text { Katering }\end{array}$ & Keterangan \\
\hline 1 & Ya & 21 & 133.000 & 124.000 & \\
\hline 2 & Ya & 7 & 105.000 & 108.000 & \\
\hline 3 & Ya & 5 & 112.000 & 115.000 & \\
\hline 4 & Ya & 5 & 98.500 & 102.500 & \\
\hline 5 & Ya & 4 & 106.500 & 110.500 & \\
\hline 6 & Ya & - & 103.000 & 106.000 & \\
\hline 7 & Tidak & - & - & 135.000 & Kebutuhan \\
& & & & & ekstrim \\
\hline 8 & ya & 4 & 124.500 & 119.000 & \\
\hline 9 & Ya & - & 102.500 & 104.000 & \\
\hline 10 & ya & - & 113.000 & 109.000 & \\
\hline
\end{tabular}


Penerapan sistem dalam proses penyusunan menu makanan di Kantin Shintya, penggunaan metode enumerasi implisit cukup mewakili proses yang ada. Bila sistem dijalankan dengan menggunakan otomatisasi pemilihan menu makanan, maka menu yang dipergunakan dalam seminggu menjadi sangat variatif. Sedangkan bila sistem dijalankan dengan menggunakan pemilihan menu makanan secara manual, maka kemungkinan untuk mendapatkan hasil penyelesaian akan berkurang. Hal ini disebabkan karena user tidak dapat menerka kandungan nutrisi dari menu yang dipilih sehingga sering kali kebutuhan pelanggan tidak terpenuhi.

Dengan melihat hasil pengujian pada tabel 1, terdapat beberapa kendala yang menjadi permasalah dalam proses pengujian antara lain: proses yang benar-benar random, data menu yang ada tidak dapat mewakili kebutuhan kalori yang ekstrim, dan juga dengan adanya banyak data pelanggan, menu yang dipergunakan dalam sehari menjadi sangat variatif.

\subsection{Evaluasi Metode Enumerasi Implisit}

Pengujian metode enumerasi implisit dilakukan dengan melakukan proses penyusunan menu dan mengubah jumlah menu makanan yang masuk dalam proses perhitungan. Dari pengujian ini didapatkan data sebagai berikut:

Tabel 2.

Tabel Pengujian Metode

\begin{tabular}{|l|l|l|l|}
\hline $\begin{array}{c}\text { Jumlah Makanan } \\
\text { Yang Diuji }\end{array}$ & $\begin{array}{c}\text { Jumlah } \\
\text { Penyelesaian Yang } \\
\text { Mungkin }\end{array}$ & $\begin{array}{c}\text { Rerata Jumlah Node } \\
\text { Akhir Dengan Enumerasi } \\
\text { Implisit }\end{array}$ & $\begin{array}{c}\text { Persentase } \\
\text { Jumlah Node } \\
\text { yang dicek }\end{array}$ \\
\hline 10 & 1.024 & 280 & $27,3 \%$ \\
\hline 11 & 2.048 & 471 & $22,9 \%$ \\
\hline 12 & 4.096 & 855 & $20,9 \%$ \\
\hline 13 & 8.192 & 1323 & $16,1 \%$ \\
\hline 14 & 16.384 & 2127 & $12,9 \%$ \\
\hline 15 & 32.768 & 3576 & $10,9 \%$ \\
\hline
\end{tabular}

Dengan melihat data pada tabel 2, didapatkan beberapa karakteristik metode enumerasi implisit sebagai berikut:

- Jumlah kedalaman dan lebar tree yang dibangun dengan menggunakan metode enumerasi implisit berbanding lurus dengan jumlah menu makanan yang digunakan dalam perhitungan. 
- Semakin banyak jenis makanan yang dipergunakan dalam proses perhitungan maka proses perhitungan menjadi lebih lama. Namun persentase penjelajahan node-nya menjadi lebih kecil.

Selain pengujian di atas, dilakukan pula sebuah proses pengujian mengenai pengaruh proses pengacakan menu makanan. Pada pengujian ini, diambil sebuah data pelanggan dan diuji sebanyak 10 kali dengan melakukan proses pemilihan menu menggunakan proses pengacakan.Dari pengujian tersebut, didapatkan data sebagai berikut:

Tabel 3.

Tabel Hasil Pengacakan

\begin{tabular}{|l|l|l|}
\hline Nomor Pengujian & Munculnya Menu Baru & Total Harga \\
\hline 1 & 21 & 105.500 \\
\hline 2 & 7 & 103.000 \\
\hline 3 & 4 & 105.000 \\
\hline 4 & 5 & 102.000 \\
\hline 5 & - & 106.000 \\
\hline 6 & 2 & 103.500 \\
\hline 7 & 3 & 104.500 \\
\hline 8 & - & 103.000 \\
\hline 9 & - & 105.500 \\
\hline 10 & 2 & 104.500 \\
\hline
\end{tabular}

Pada tabel 3 dapat dilihat bahwa dengan menggunakan data yang sama selalu ada perbedaan antara menu yang muncul. Hal ini disebabkan oleh proses pengacakan yang dilakukan sebelum proses enumerasi implisit dilakukan. Dengan adanya proses pengacakan ini, hasil susunan menu yang didapat pun menjadi tidak tetap. Karenanya, sulit bagi sistem untuk mendapatkan susunan menu yang 100\% sama.

\section{KESIMPULAN}

Berdasarkan hasil implementasi dan analisis sistem yang menggunakan metode Enumerasi Implisit, maka didapat kesimpulan sebagai berikut:

a) Penggunaan metode enumerasi implisit dapat menyelesaikan masalah penyusunan menu diet berdasarkan kebutuhan kalori. Semakin banyak jenis makanan yang dipergunakan, persentase penjelajahan node-nya menjadi lebih kecil

b) Dalam penggunaan secara nyata metode enumerasi implisit kadang tidak dapat mewakili proses penyusunan menu makanan secara keseluruhan sehingga hasil akhir yang didapat belum tentu optimal. 
c) Jumlah kedalaman dan lebar tree yang dibangun dengan menggunakan metode enumerasi implisit berbanding lurus dengan jumlah menu makanan yang digunakan dalam perhitungan

\section{Daftar Pustaka}

Beal, Dennis. (2008). An Exact Implicit Enumeration Algorithm for Variable Selection in

Multiple Linear Regression Models Using Information Criteria. Diakses 25 Maret 2012, dari analytics.ncsu.edusesug2011ST10.Beal.pdf

Beal, Dennis. (2009). Operation Research in Linear Optimization. Indianapolis: Wiley

Haas, Elson M; Buck Levin. (2006). Staying Healthy with nutrition. Ohio: Celestial Arts

Mahan, L. Kathleen; Sylvia Escott-Stump. (2008). Krause's Food \& Nutrition Therapy. Canada: Saunders Elvesier.

Mahmud, Mien K; Nils Aria Zulfianto. (2009). Tabel Komposisi Pangan Indonesia. Jakarta : Elex Media Komputindo

Milikainen, Taneli (2009). Implicit Enumeration of Pattern. Diakses 27 Maret 2012, dari http://citeseerx.ist.psu.edu/viewdoc/download?doi=10.1.1.58.7820\&rep=rep1\&type=pdf

Sabagh, M.S. (2008). A Generalized Implicit Enumeration Algorithm for a Class of Integer Nonlinear Proggraming. Diakses 27 Maret 2012, dari www.sid.irenVEWSSIDJ_pdf1 17320080607.pdf

Siang, Jong Jek. (2011). Riset Operasi dalam Pendekatan Algoritmis. Yogyakarta: Andi Publisher 